\title{
Spray-dried porcine plasma added to diets contaminated with aflatoxins and fumonisins shows beneficial effects to piglet health
}

\author{
LUCIELI K.F. MÜLLER ${ }^{1}$, DIOVANI PAIANO ${ }^{1}$, NATHIELI B. BOTTARI ${ }^{2}$, JANIO M. SANTURIO ${ }^{3}$, \\ ALINE ZAMPAR ${ }^{1}$, MARIA R.C. SCHETINGER ${ }^{3}$, RÉGIS A. ZANETTE ${ }^{4}$, RICARDO E. MENDES ${ }^{5}$, \\ EDUARDO M. GLORIA ${ }^{6}$, MATHEUS D. BALDISSERA ${ }^{3}$ and ALEKSANDRO S. DA SILVA ${ }^{1,2}$
}

\author{
${ }^{1}$ Programa de Pós-Graduação em Zootecnia, Universidade do Estado de Santa Catarina/UDESC, \\ Rua Beloni Trombeta Zanin, 680E, Santo Antônio, 89815-630 Chapecó, SC, Brazil \\ ${ }^{2}$ Programa de Pós-Graduação em Bioquímica Toxicológica, Universidade Federal de Santa \\ Maria/UFSM, Av. Roraima, 1000, 97105-900 Santa Maria, RS, Brazil \\ ${ }^{3}$ Departamento de Microbiologia e Parasitologia, Universidade Federal de Santa Maria/ \\ UFSM, Av. Roraima, 1000, 97105-900 Santa Maria, RS, Brazil \\ ${ }^{4}$ Departamento de Farmacologia, Universidade Federal do Rio Grande do Sul, Av. \\ Paulo Gama, 110, Farroupilha, 90040-060 Porto Alegre, RS, Brazil \\ ${ }^{5}$ Laboratório de Patologia, Instituto Federal Catarinense, Rodovia SC 283, s/n,Vila Fragosos, 89700-000 Concórdia, SC, Brazil \\ ${ }^{6}$ Laboratório de Micologia, Universidade de São Paulo, Av. Dr. Enéas Carvalho de Aguiar, 470, 05403-000 São Paulo, SP, Brazil
}

Manuscript received on October 10, 2017; accepted for publication on February 5, 2018

\begin{abstract}
This study was aimed to analyze the effects of spray-dried porcine plasma (SDPP) on the health of post weaning piglets challenged with diets contaminated with aflatoxins and fumonisins. Fifty-six male piglets $(7.15 \pm 0.61 \mathrm{~kg})$ were allocated in four groups: CTL group received a regular diet; SDPP group received a regular diet and 6\% SDPP; MYC group received a diet containing $300 \mu \mathrm{g} / \mathrm{kg}$ aflatoxins and 8,000 $\mu \mathrm{g} / \mathrm{kg}$ fumonisins; group MYC+SDPP received $300 \mu \mathrm{g} / \mathrm{kg}$ aflatoxins, $8,000 \mu \mathrm{g} / \mathrm{kg}$ fumonisins and $6 \% \mathrm{SDPP}$. The animals that received the experimental diet containing mycotoxins (MYC group) had lower weight gain at the end of the experiment compared to the other treatments. Animals receiving SDPP showed decreased urea levels throughout the experiment $(P<0.05)$. Animals from MYC group presented an increased on reactive oxygen species (ROS) and thiobarbituric acid reactive substances (TBARS) levels and decreased catalase activity $(P<0.05)$. In contrast, SDPP prevented the increase of ROS and TBARS and stimulated superoxide dismutase activity $(P<0.05)$. In conclusion, diet contaminated with mycotoxins (group MYC) caused subclinical intoxication in the piglets, as observed by the increase on free radical's production and lipid peroxidation. Conversely, SDPP presented a protective effect, minimizing the effects of oxidative stress caused by aflatoxins and fumonisins ingestion.
\end{abstract}

Key words: Functional foods, intoxication, mycotoxins, pigs, health.

Correspondence to: Aleksandro Schafer da Silva

E-mail: aleksandro_ss@yahoo.com.br

Diovani Paiano

E-mail: diovani@hotmail.com 


\section{INTRODUCTION}

Mycotoxins are toxic compounds produced by filamentous fungi that challenge pigs in the most diverse production cycle stages (Freitas et al. 2012). However, at weaning, piglets are more vulnerable to functional disorders, given the stresses of the various changes at this stage (Sugiharto et al. 2014). At high doses, mycotoxins can trigger problems of various orders, such as altering enzyme activity (Dilkin et al. 2010), serum biochemical variables, histology and functionality of some organs (Olinda et al. 2016), inducing oxidative stress ( $\mathrm{Fu}$ et al. 2013) and compromising animal consumption and performance (Pastorelli et al. 2012).

Many strategies are used to mitigate the harmful effects of weaning, including the use of functional foods. Among the functional foods used for piglets, we highlight the spray-dried porcine plasma (SDPP), which is considered a high-quality protein capable to improve the palatability and feed consumption (Pujols et al. 2016). SDPP has anti-inflammatory properties due to the presence of active immunoglobulins that act on the intestinal barrier and prevent adhesion of pathogenic bacteria to the wall of the intestine (Hedegaard et al. 2016). In addition, dietary SDPP enhances immunity (Campbell et al. 2016) and reduces the activation of the immune system (Campbell et al. 2008). The benefits of SDPP in piglet weaning are considered as one of the most important discoveries in pig nutrition in the last 100 years (Crowmell 2009). In this sense, a recent study conducted by Muller et al. (2017) demonstrated that $6 \%$ of SDPP in the diet prevents the reduction on leukocyte levels, the negative effects associated with performance and minimize the inflammatory response of piglets intoxicated with aflatoxins and mycotoxins, considering this treatment an interesting approach to modulate the inflammatory process and improve the immune system.
The impacts of SDPP supplementation on the health of pigs fed diets containing mycotoxins have been scarcely explored. Therefore, this study aimed to verify whether the addition of SDPP to postweaning piglet diets contaminated with containing $300 \mu \mathrm{g} / \mathrm{kg}$ aflatoxins and $8,000 \mu \mathrm{g} / \mathrm{kg}$ fumonisins is able to avoid or minimize the effects caused by mycotoxin intoxication.

\section{MATERIALS AND METHODS}

\section{MYCOTOXINS}

The mycotoxin production used in this study was previously detailed by Muller et al. (2017). Aflatoxins were obtained by the rice fermentation method, with controlled temperature and constant stirring, and the Aspergillus parasiticus strain was used to production of mycotoxin. Fumonisins were obtained from fermentation of corn grains, the Fusarium verticillioides strain was used to production of mycotoxin. The mycotoxin contamination levels proposed in our study were achieved in the diets by adding these concentrated mycotoxins. Notwithstanding, control diet were obtained by using naturally contaminated soybean and corn meals.

\section{ANIMALS AND CONDITIONS}

Fifty-six commercial line castrated piglets, weighing $7.2 \pm 0.61 \mathrm{~kg}$ were weaned at $24 \pm 2$ days. The piglets were housed in pairs in metal cages measuring $1.2 \times 0.5 \mathrm{~m}$, with plastic leaked floor, equipped with manual feeders and troughs. Room temperature was set at $23-25^{\circ} \mathrm{C}$ and was controlled by automated electric heaters. The present study was approved by the Ethics Committee of the State University of Santa Catarina, according to approval protocol number 01.34.15.

\section{EXPERIMENTAL DESIGN}

Four isonutritive diets were formulated according to minimum nutritional requirements recommended 
by Rostagno et al. (2011), with maize and soybean meals as the main ingredients of the diet (Table I). The four diets corresponded to the four treatments provided to the groups of postweaning animals, differing by the level of contamination of aflatoxins and fumonisins and by the addition or not of $6 \%$ SDPP, as follows: CTL (Control diet: $0.95 \mu \mathrm{g}$ / $\mathrm{kg}$ aflatoxins and $450 \mu \mathrm{g} / \mathrm{kg}$ fumonisins); SDPP (control diet: $0.95 \mu \mathrm{g} / \mathrm{kg}$ aflatoxins, $450 \mu \mathrm{g} / \mathrm{kg}$ fumonisins and 6\% SDPP); MYC (experimental diet: $300 \mu \mathrm{g} / \mathrm{kg}$ aflatoxins and $8000 \mu \mathrm{g} / \mathrm{kg}$ fumonisins); MYC + SDPP (experimental diet: 300 $\mu \mathrm{g} / \mathrm{kg}$ aflatoxins, $8000 \mu \mathrm{g} / \mathrm{kg}$ fumonisins and $6 \%$ SDPP). The weight of the litter was scheduled on days 1 and 15 of the experiment, using a digital scale.

\section{SAMPLE COLLECTION}

The experimental period comprised the first 15 days after weaning. Blood samples were collected using vacutainer tubes at days 5, 10 and 15 after diet consumption. Subsequently, serum was obtained by centrifugation at $8,000 \mathrm{rpm}$ for 10 minutes. Blood was also collected in tubes with sodium citrate for analysis of catalase (CAT) and superoxide dismutase (SOD) activities. Whole blood and serum were kept at $-20{ }^{\circ} \mathrm{C}$ until analysis.

At day 15 of experiment, five animals per group were euthanized. Liver fragments were removed and fixed in $10 \%$ formalin buffer for histopathological analysis. Liver fragments were also collected and homogenized in $10 \mathrm{mM}$ Tris$\mathrm{HCl}$ buffer ( $\mathrm{pH}$ 7.4) for analysis of thiobarbituric acid reactive substances (TBARS) and reactive oxygen species (ROS) levels, as well as the CAT and SOD activities.

\section{SERUM BIOCHEMISTRY}

Serum was used to evaluate alanine aminotransferase (ALT) and gammaglutamyltransferase (GGT) activities, as well as total protein, albumin, globulins, urea, cholesterol and triglyceride levels. Analyzes were performed using commercial kits (Analisa ${ }^{\circledR}$ ), following the manufacturer's instructions in a semiautomatic biochemical analyzer (Bioplus 2000 ${ }^{\circledR}$ ). Globulin levels were calculated as the difference between total proteins and albumin.

\section{LEVELS OF FREE RADICALS AND LIPID PEROXIDATION IN SERUM AND LIVER}

ROS and TBARS levels were measured to determine free radicals and lipid peroxidation in the serum and liver of the piglets, respectively. ROS levels were determined in serum and in liver homogenates according to the method described by Ali et al. (1992). Samples were diluted 1:10 (v:v) in $10 \mathrm{mM}$ Tris-Hcl, pH 7.4, and $5 \mu 1$ of dichlorofluorescein diacetate (DCFH-DA) were added according the methodology described by Bass et al. (1983). The results were expressed in U DCFA $/ \mu \mathrm{L}$. TBARS levels in serum were analyzed according to the method described by Jentzsch et al. (1996) and expressed in nmol malondialdehyde (MDA)/mL. Liver fragments were homogenized in $50 \mathrm{mM}$ Tris$\mathrm{Hcl}, \mathrm{pH}$ 7, and centrifuged at 2,500 rpm for $15 \mathrm{~min}$. The supernatant $(\mathrm{S} 1,200 \mu \mathrm{L})$ was incubated at 95 ${ }^{\circ} \mathrm{C}$ for $60 \mathrm{~min}$ in acidic medium with $8.1 \%$ sodium dodecyl sulfate, $0.5 \mathrm{~mL}$ acetic acid buffer (500 $\mathrm{mM}, \mathrm{pH} 3.4$ ) and $0.6 \%$ thiobarbituric acid (TBA). TBARS levels were measured at $532 \mathrm{~nm}$ according to the method of Ohkawa et al. (1978). The results were expressed in nmol MDA/mg of protein.

\section{ANTIOXIDANT ENZYMES}

The activity of the antioxidant enzymes CAT and SOD was analyzed in whole blood and in hepatic homogenates. CAT activity was measured according to the method described by Nelson and Kiesow (1972), and expressed in nmol CAT/mg protein. SOD activity was quantified according to the technique described by McCord and Fridovich (1969), and expressed in U SOD/mg of protein. 
Fragments of the right medial lobe of the liver and of the intestine (duodenum and jejunum) were collected and fixed in $10 \%$ buffered formalin solution. Samples were routinely processed and stained with hematoxylin and eosin (H\&E) for histopathological analysis. Moreover, images of intestinal histopathology were selected to measure villi height and crypt depth (12 per image per blade) from duodenum, jejunum and ileum. The thickness of the mucosa was also measured in the respective reading points according the protocol described by Teixeira et al. (2003). ImageJ software was used for the measurements.

\section{STATISTICAL ANALYSIS}

A $2 \times 2$ completely randomized design (DIC) was used, with two plasma levels (with or without $6 \%$ SDPP inclusion) and contaminated or not of aflatoxins and fumonisins, with a total of four treatments with 14 replicates for blood variables, five for liver tissue analysis and one animal per experimental unit. The data were submitted to Shapiro-Wilk and Kolmogorov-Smirnov normality tests and the residues were transformed when necessary to meet the normality assumption. Thereafter, variables were submitted to analysis of variance using the statistical package SAS 9.2, according to the mathematical model: $Y_{\mathrm{ijk}}=\mu+A_{\mathrm{i}}$ $+\mathrm{B}_{\mathrm{j}}+(\mathrm{AB})+\mathrm{e}_{\mathrm{ijk}}$ where: $\mathrm{Y}=$ response variable; $\mu=$ the overall mean of the experiment for the variable (overall mean associated with all observations); $\mathrm{A}_{\mathrm{i}}$ $=$ effect of the $\mathrm{i}$-th plasma level; $\mathrm{B}_{\mathrm{j}}=$ effect of $\mathrm{j}$-th mycotoxin level; $A_{i} * B_{j}=$ interaction effect $A x B ; e_{i j k}$ $=$ random error. One-way ANOVA was performed using repeated measurements to test difference in the parameters over time (considering blocks of groups) $P<0.05$ was considered statistically significant.
No hepatic and intestinal (duodenum and jejunum) lesions were observed in the studied groups (data not showed). No differences were observed between groups $(P>0.05)$ for crypt depth, villus height and mucosal thickness in the gut of the piglets (data not shown).

The treatments evaluated did not promote histopathological alterations in the liver and intestine. Moreover, no differences were observed in the activities of the liver enzymes ALT and GGT $(P>0.05)$. The MYC diet also did not affect liver functions related to protein synthesis and lipid metabolism, as the biochemical parameters indicative of these activities such as total proteins, albumin, cholesterol and triglycerides were not altered $(P>0.05)$. Globulin levels were also not influenced $(P>0.05)$ by the treatments (Table II). However, serum urea levels (Table II) were lower $(P<0.05)$ in piglets that consumed SDPP in the three periods analyzed.

Seric TBARS levels (Table III) were lower $(P<0.05)$ in piglets that consumed SDPP in the three periods analyzed. At day 5 of treatment, serum ROS levels were increased in pigs from MYC group compared to CTL group $(P<0.05)$ (Table IV). However, at days 10 and 15 in serum (Table IV) and day 15 in liver (Table V) ROS levels interacted with SDPP and mycotoxin factors $(P<0.05)$, i.e., SDPP was able to neutralize the mycotoxin-induced increase of ROS levels. In SDPP-free diets, hepatic TBARS levels were increased $(P<0.05)$ in the presence of mycotoxins (Table V). However, when compared to the treatment with CTL group, TBARS levels were higher $(P<0.05)$ when SDPP was added to the diet. At day 15 in liver (Table V) TBARS levels interacted with SDPP and mycotoxin factors $(P<0.05)$, i.e. SDPP was able to minimize the negative effects caused by mycotoxin (Table V).

Blood (Table III) and liver (Table V) CAT activities were decreased $(P<0.05)$ in the group 
TABLE I

Composition of experimental diets. Adapted table of Muller et al. (2017). CTL: control diet; SDPP: control diet and $6 \%$ of SDPP; MYC: $300 \mu \mathrm{g} / \mathrm{kg}$ aflatoxins $+8,000 \mu \mathrm{g} / \mathrm{kg}$ fumonisins; MYC+SDPP: $300 \mu \mathrm{g} / \mathrm{kg}$ aflatoxins $+8,000 \mu \mathrm{g} / \mathrm{kg}$ of fumonisins $+6 \%$ SDPP.

\begin{tabular}{|c|c|c|c|c|}
\hline & CTL & SDPP & MYC & MYC+SDPP \\
\hline \multicolumn{5}{|l|}{ Calculated composition } \\
\hline Aflatoxins, $\mu \mathrm{g} / \mathrm{kg}$ & 0.95 & 0.95 & 300 & 300 \\
\hline Fumonisins, $\mu \mathrm{g} / \mathrm{kg}$ & 450 & 450 & 8,000 & 8,000 \\
\hline \multicolumn{5}{|l|}{ Ingredients, $\%$} \\
\hline Corn & 39.43 & 46.33 & 33.23 & 40.11 \\
\hline Soybean meal (45\%) & 31.38 & 20.25 & 30.43 & 19.31 \\
\hline Whey powder & 15.0 & 15.0 & 15.0 & 15.0 \\
\hline Sugarcane & 5.0 & 5.0 & 5.0 & 5.0 \\
\hline Dicalcium phosphate & 1.29 & 1.23 & 1.30 & 1.24 \\
\hline Limestone & 0.74 & 0.82 & 0.74 & 0.84 \\
\hline Soybean oil & 3.40 & 2.11 & 3.35 & 2.08 \\
\hline Vitamin supplement $^{1}$ & 0.30 & 0.30 & 0.30 & 0.30 \\
\hline Mineral supplement ${ }^{2}$ & 0.30 & 0.30 & 0.30 & 0.30 \\
\hline Zinc oxide & 0.25 & 0.25 & 0.25 & 0.25 \\
\hline Salt & 0.37 & 0.04 & 0.37 & 0.04 \\
\hline L-Lysine H-Cl & 0.84 & 0.75 & 0.86 & 0.78 \\
\hline DL-Methionine & 0.38 & 0.34 & 0.38 & 0.34 \\
\hline L-Threonine & 0.45 & 0.38 & 0.45 & 0.38 \\
\hline L-Tryptophan & 0.08 & 0.08 & 0.08 & 0.09 \\
\hline L-Isoleucine & 0.20 & 0.29 & 0.21 & 0.30 \\
\hline L-Valine & 0.58 & 0.52 & 0.59 & 0.52 \\
\hline Spray-dried porcine plasma & - & 6.0 & - & 6.0 \\
\hline Isolated aflatoxins & - & - & 0.23 & 0.23 \\
\hline Isolated fumonisin & - & - & 6.91 & 6.88 \\
\hline \multicolumn{5}{|l|}{ Chemical composition } \\
\hline Metabolizable energy, Mcal $/ \mathrm{kg}$ & 3.40 & 3.40 & 3.40 & 3.40 \\
\hline Crude Protein, \% & 21.0 & 21.0 & 21.0 & 21.0 \\
\hline Neutral detergent fiber, $\%$ & 8.98 & 8.25 & 8.12 & 7.39 \\
\hline Acid detergent fiber, $\%$ & 3.96 & 3.29 & 3.66 & 3.00 \\
\hline
\end{tabular}

${ }^{1}$ Provided the following per kilogram of diet: Vitamin A - 4.167.000 UI, Vitamin D3 - 833.000 UI, Vitamin E - 13.333 mg, Vitamin K3 - $1.000 \mathrm{mg}$, Vitamin B1 - $1.000 \mathrm{mg}$, Vitamin B2 - $1.667 \mathrm{mg}$, Vitamin B6 - $1.000 \mathrm{mg}$, Vitamin B12 - $8 \mathrm{mg}, \mathrm{Niacin}-11.667$ mg, Pantothenic Acid - $7.333 \mathrm{mg}$, Folic acid - $200 \mathrm{mg}$, Colin - $104 \mathrm{mg}$, Biotin - $33 \mathrm{mg} ;{ }^{2}$ Calcium (min. $166 \mathrm{~g}$ and max. $203 \mathrm{~g}$ ), Cobalt - 266.7 mg, Cooper - $66.67 \mathrm{~g}$, Iodine $-600 \mathrm{mg}$, magnesium - $18.3 \mathrm{~g}$, Selenium - $135 \mathrm{mg}$, Zinc $-41.67 \mathrm{~g}$, Iron - $66.67 \mathrm{~g}$, $40 \mathrm{mg} / \mathrm{kg}$ growth promoter. 
LUCIELI K.F. MÜLLER et al.

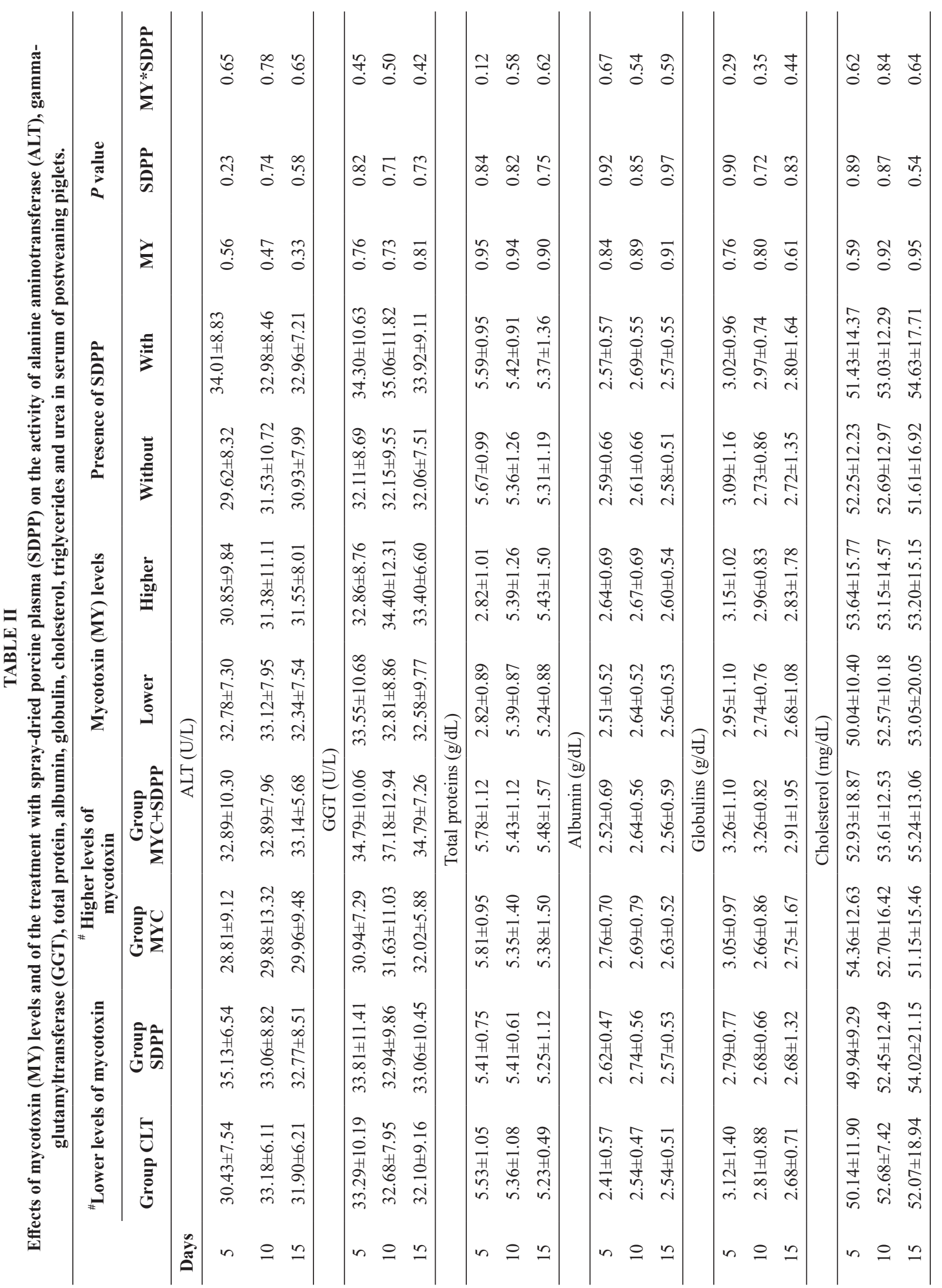




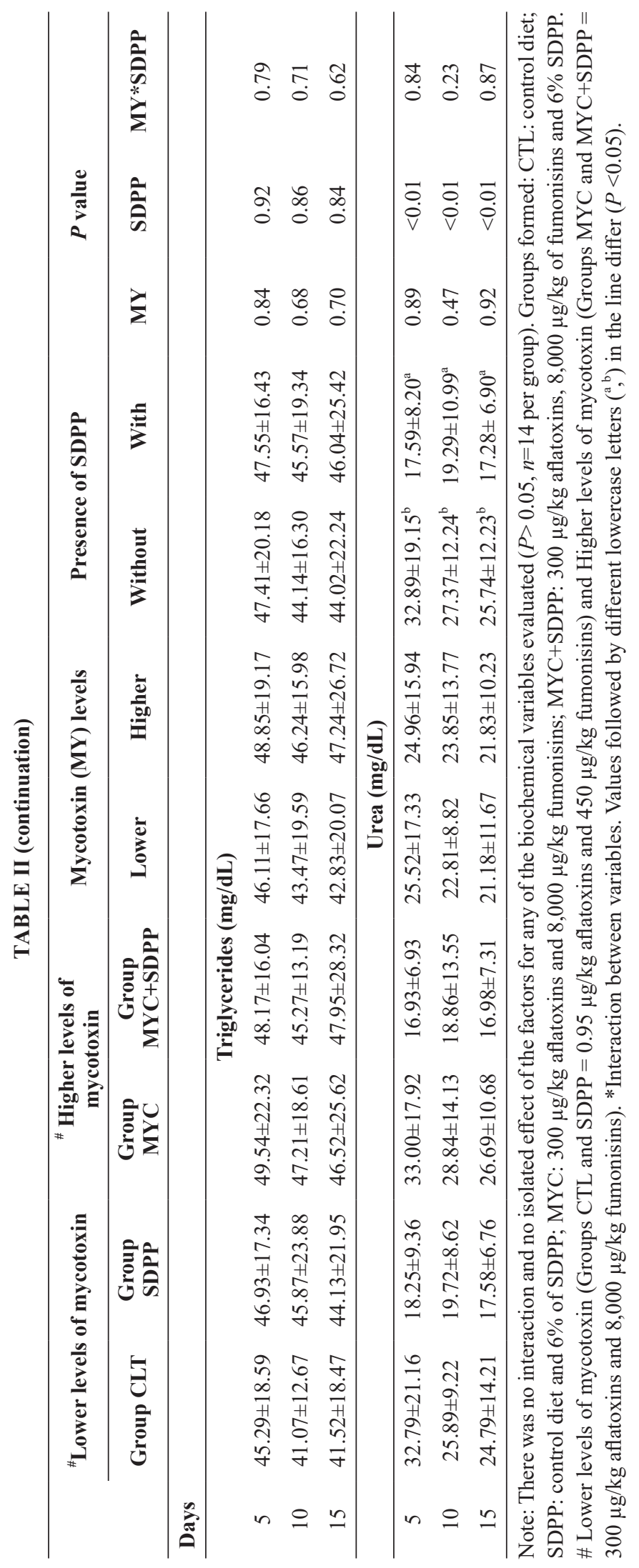




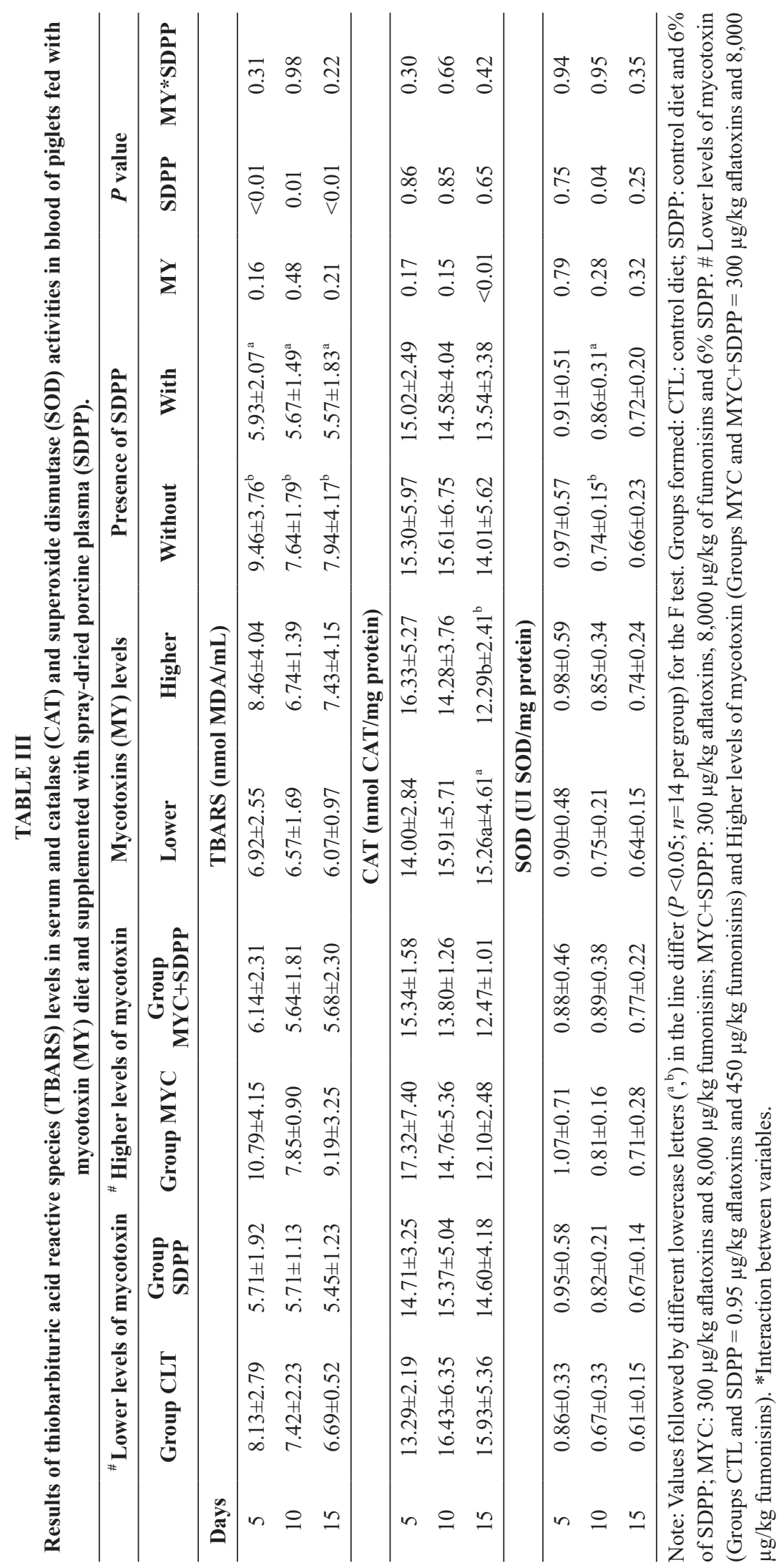


MYC at day 15 of experiment. Blood SOD activity was increased at day 10 in the diet with SDPP $(P<0.05)$. Conversely, an interaction was observed in liver SOD activity (Table V), i.e., SOD activity was increased in animals treated with SDPP and receiving a MYC group $(P<0.05)$.

The animals that received the MYC group had lower weight gain at the end of the experiment (day 15) compared to the other treatments $(P<0.05)$. Numerically, animals receiving SDPP had higher final weight and weight gain at days 15 of experiment (Table VI). At day 15 to weight and day 1-15 to weight gain have interacted of SDPP and mycotoxin factors $(P<0.05)$, i.e. SDPP was able to minimize the negative effects caused by mycotoxin for growth (Table VI).

Over time (days 5 to 10 ; and 5 to 15 ; and 10 to 15$)$, no significant difference was observed $(P>0.05)$ to serum biochemistry (ALT, GGT, urea, triglycerides, cholesterol, total protein, albumin and globulin), serum and liver oxidants (TBARS and ROS) and antioxidant enzymes in the blood and liver (CAT and SOD). Over time (days 5 to 15), a significant difference was observed for the four groups regarding body weight $(P<0.001)$, that is, there was an increase in the weight of the animals that were in the growth phase.

\section{DISCUSSION}

The lack of clinical signs in the piglets of this study is likely to be due to the low mycotoxin levels and mainly to the short experimental course that were not sufficient to cause severe intoxication, to damage the liver and to alter biochemical variables related to health and liver function. Subclinical intoxication similar to observed in our study was obtained by Weaver et al. (2014), who reported that diets containing aflatoxins (250 parts-per-billion (ppm)), fumonisins (6.9 parts-per-million (ppm)) and SDPP fed to animals for three weeks did not change biochemical variables, total proteins, albumin, globulins and cholesterol levels and ALT activity.

Fu et al. (2013) fed piglets for 42 days with diets containing 5 and $373 \mathrm{ppb}$ of aflatoxins and did not observe effects on the activity of ALT and GGT enzymes and on serum levels of total proteins, urea and albumin. Dilkin et al. (2010) challenged $25 \mathrm{~kg}$ pigs with a dose of $125 \mathrm{ppm}$ fumonisins administered to fasted animals by using an esophageal catheter. Clinical signs observed included lethargy, increased respiratory rate, increased cardiac frequency, lateral decubitus as the preferential position and reduction of food and water consumption. However, no histopathological changes were observed in the liver, as well in the activities of ALT and alkaline phosphatase (ALP), and in the levels of total protein and albumin. We believe that these variables are not good markers to identify mycotoxin poisoning in piglets at the doses or at the time evaluated in our study, differing from a severe intoxication (Olinda et al. 2016). Therefore, more sensitive markers are needed.

The results of this study clearly demonstrated the beneficial effects of SDPP supplementation. Body weight gain significantly improved in the animals that receive SDPP diet during the experiment. From a nutritive perspective, this improvement in the growth performance may be due to nutrient utilization, a high quality protein with a high amino acid profile that can support weight gain and rapid muscle growth. Moreover, according to Ermer et al. (1994), the SDPP has a good diet palatability improving the immunocompetence of animals.

Consumption of SDPP reduced serum urea levels. Urea is considered an indicator of the quality of dietary protein. Dalto et al. (2011) reported a reduction in plasma urea levels with the use of SDPP for piglets at 35 days of age with consumption of $20 \mathrm{~g}$ of SDPP per day. The same results were found by Weaver et al. (2014) who 
observed lower levels of circulating urea in animals that consumed plasma after weaning.

The elevation of blood SOD activity at day 15 after SDPP treatment is likely to be a compensatory effect related to the reduction of CAT caused by consumption of a diet contaminated with mycotoxins, which also increased ROS levels. According to Oliveira et al. (2009), this probably can be explained by an increase in the production of antioxidants due to generation of ROS, which was observed in our study.

A reduction of the antioxidant enzymes SOD and CAT in the blood and an increase of SOD in the liver were reported by $\mathrm{Fu}$ et al. (2013) as indicative of aflatoxin (372.8 ppb) intoxication, but no oxidation indicators were analyzed. Induction of mycotoxin-associated oxidative stress was also found by Theumer et al. (2010) with experimental doses of $40 \mathrm{ppb}$ aflatoxins and $100 \mathrm{ppm}$ fumonisins administered to rats. The authors also reported an increase of TBARS levels and CAT and SOD activities. Biomarkers of genetic damage were also evaluated by Theumer et al. (2010) who found a direct correlation of DNA damage with oxidative stress markers. Therefore, the authors suggested that mycotoxins induce indirectly genotoxicitymediated oxidative stress.

The potential of SDPP to counteract oxidative stress observed in our study corroborates the findings of Gao (2014) in an experiment with piglets aging 3 to 21 days. The author reported that the addition of 10\% SDPP to diets reduced serum TBARS levels and elevated CAT activity in the intestinal mucosa. According to Torrallardona (2010), SDPP diet acts reducing proinflammatory cytokines by impairing the adhesion of pathogens to the intestinal wall, since one of the attributes of SDPP is the presence of specific active immunoglobulins for some enteric pathogenic bacteria. According to Soares et al. (2015), ROS can induce the production of proinflammatory cytokines, leading again to ROS production, therefore triggering a vicious circle
TABLE IV

Levels of reactive oxygen species (ROS) in serum of piglets fed with mycotoxin diet and supplemented with spray-dried porcine plasma (SDPP). Note: At days 10 and 15 serum ROS levels interacted with SDPP and mycotoxin factors $(P<0.05)$, i.e., SDPP was able to neutralize the mycotoxin-induced increase of ROS levels.

\begin{tabular}{|c|c|c|c|c|}
\hline \multicolumn{5}{|c|}{ Serum ROS (U DCFA/ $\mu \mathrm{L})$} \\
\hline & $\begin{array}{c}{ }^{\#} \text { Lower } \\
\text { levels of } \\
\text { mycotoxin }\end{array}$ & $\begin{array}{c}{ }^{\#} \text { Higher } \\
\text { levels of } \\
\text { mycotoxin }\end{array}$ & Means & $P$ \\
\hline \multicolumn{5}{|c|}{ Day 5} \\
\hline $\begin{array}{l}\text { Without } \\
\text { SDPP }\end{array}$ & $1.325 \pm 234$ & $2.451 \pm 1.183$ & $1.888 \pm 1.053$ & 0.43 \\
\hline $\begin{array}{l}\text { With } \\
\text { SDPP }\end{array}$ & $1.346 \pm 200$ & $1.702 \pm 453$ & $1.524 \pm 376$ & 0.26 \\
\hline Means & $1.335 \pm 207$ & $2.076 \pm 968$ & & 0.04 \\
\hline$P$ & 0.89 & 0.19 & 0.31 & \\
\hline \multicolumn{5}{|c|}{ Day 10} \\
\hline $\begin{array}{l}\text { Without } \\
\text { SDPP }\end{array}$ & $1.315 \pm 272$ & $2.255 \pm 750$ & $1.785 \pm 908$ & 0.01 \\
\hline $\begin{array}{l}\text { With } \\
\text { SDPP }\end{array}$ & $1.418 \pm 461$ & $1.614 \pm 578$ & $1.516 \pm 510$ & 0.54 \\
\hline Means & $1.366 \pm 396$ & $1.940 \pm 873$ & & 0.35 \\
\hline$P$ & 0.47 & 0.02 & 0.79 & \\
\hline \multicolumn{5}{|c|}{ Day 15} \\
\hline $\begin{array}{l}\text { Without } \\
\text { SDPP }\end{array}$ & $1.389 \pm 196$ & $2.393 \pm 339$ & $1.891 \pm 698$ & 0.001 \\
\hline $\begin{array}{l}\text { With } \\
\text { SDPP }\end{array}$ & $1.381 \pm 416$ & $1.447 \pm 471$ & $1.414 \pm 439$ & 0.85 \\
\hline Means & $1.385 \pm 331$ & $1.920 \pm 871$ & & 0.15 \\
\hline$P$ & 0.92 & 0.001 & 0.65 & \\
\hline
\end{tabular}

Note: Different to $P<0.05$ ( $n=14$ per group) by the F test. ${ }^{*}$ Lower levels of mycotoxin (Groups CTL and SDPP $=0.95$ $\mu \mathrm{g} / \mathrm{kg}$ aflatoxins and $450 \mu \mathrm{g} / \mathrm{kg}$ fumonisins) and Higher levels of mycotoxin (Groups MYC and MYC+SDPP $=300 \mu \mathrm{g} / \mathrm{kg}$ aflatoxins and $8,000 \mu \mathrm{g} / \mathrm{kg}$ fumonisins).

between oxidative stress and inflammation, which would have a negative effect on animal production.

According to literature, the anti-inflammatory effect of SDPP exists (Campbell et al. 2008), since SDPP stimulates the production of interleukin-10 (IL-10), which has anti-inflammatory properties. Perez-Bosque et al. (2016) found an increase in the amount of IL-10 and a reduction of proinflammatory 
TABLE V

Results of reactive oxygen species analysis (ROS), thiobarbituric acid reactive species (TBARS), catalase (CAT) and superoxide dismutase (SOD) in the liver of piglets fed with mycotoxin diet and supplemented with spray-dried porcine plasma (SDPP).

\begin{tabular}{|c|c|c|c|c|}
\hline & $\begin{array}{c}{ }^{\#} \text { Lower levels of } \\
\text { mycotoxin }\end{array}$ & $\begin{array}{l}{ }^{\#} \text { Higher levels of } \\
\text { mycotoxin }\end{array}$ & Means & $P$ \\
\hline \multicolumn{5}{|c|}{$\operatorname{ROS}(\mathrm{U}$ DCFA/ $\mu \mathrm{L})$} \\
\hline Without SDPP & $579 \pm 150$ & $1.708 \pm 449$ & $1.148 \pm 669$ & 0.001 \\
\hline With SDPP & $644 \pm 189$ & $970 \pm 325$ & $807 \pm 304$ & 0.75 \\
\hline Means & $612 \pm 132$ & $1.339 \pm 537$ & & 0.05 \\
\hline$P$ & 0.80 & 0.030 & 0.24 & \\
\hline \multicolumn{5}{|c|}{ TBARS (nmol MDA/mL) } \\
\hline Without SDPP & $13.05 \pm 1.53$ & $22.70 \pm 2.76$ & $17.85 \pm 5.50$ & 0.001 \\
\hline With SDPP & $16.39 \pm 2.32$ & $20.22 \pm 4.38$ & $18.30 \pm 4.19$ & 0.14 \\
\hline Means & $14.72 \pm 1.54$ & $21.46 \pm 3.69$ & & 0.02 \\
\hline$P$ & 0.04 & 0.74 & 0.87 & \\
\hline \multicolumn{5}{|c|}{ CAT (nmol CAT/mg protein) } \\
\hline Without SDPP & $22.91 \pm 1.35$ & $21.32 \pm 2.27$ & $22.11 \pm 1.84$ & 0.45 \\
\hline With SDPP & $23.35 \pm 2.08$ & $20.83 \pm 1.33$ & $22.09 \pm 2.11$ & 0.24 \\
\hline Means & $23.13 \pm 1.69$ & $21.08 \pm 1.84$ & & 0.05 \\
\hline$P$ & 0.85 & 0.82 & 0.92 & \\
\hline \multicolumn{5}{|c|}{ SOD (UI SOD/mg protein) } \\
\hline Without SDPP & $14.76 \pm 1.86$ & $20.35 \pm 5.26$ & $17.56 \pm 4.56$ & 0.06 \\
\hline With SDPP & $14.76 \pm 1.87$ & $31.14 \pm 7.09$ & $22.95 \pm 9.92$ & 0.001 \\
\hline Means & $14.76 \pm 1.55$ & $25.75 \pm 8.40$ & & 0.07 \\
\hline$P$ & 0.98 & 0.03 & 0.14 & \\
\hline
\end{tabular}

Note: Different to $P<0.05$ ( $n=5$ per group) by the F test. "Lower levels of mycotoxin (Groups CTL and SDPP $=0.95 \mu \mathrm{g} / \mathrm{kg}$ aflatoxins and $450 \mu \mathrm{g} / \mathrm{kg}$ fumonisins) and Higher levels of mycotoxin (Groups MYC and MYC+SDPP $=300 \mu \mathrm{g} / \mathrm{kg}$ aflatoxins and $8,000 \mu \mathrm{g} / \mathrm{kg}$ fumonisins).

cytokines when $8 \%$ SDPP was added to the diet of laboratory rats, concluding that SDPP promotes activation of the immune system by reducing inflammatory response. Also, the levels of immunoglobulin $\operatorname{IgA}$ in the intestine is considered an indicator to evaluate the intestinal mucosa immunity, where high levels of IgA are released during an inflammatory process, as observed by Tran et al. (2014) in weaning piglets fed with a diet containing mycotoxins. In this sense, these same authors revealed that treatment with SDPP reduced the intestinal IgA levels, which demonstrated the anti-inflammatory effects of SDPP. According to these authors, this response can contribute to improvement of immune and antioxidant systems, as observed in this present study. Furthermore, Campbell et al. (2016) reinforce that SDPP prevents lesions of pathogenic bacteria in the intestinal wall, and thereby reduces the activation of the immune system and the production of proinflammatory cytokines by being a food that boosts the immune system and promotes health and performance of the animals.

The likely mechanism of action of plasma to reduce oxidative stress is associated with the presence of active immunoglobulins, which may have conferred protective action to the intestinal wall, as well as stimulating the production of 
TABLE VI

Weight and weight gain of piglets of fed with mycotoxin diet and supplemented with spray-dried porcine plasma (SDPP).

\begin{tabular}{|c|c|c|c|c|}
\hline & $\begin{array}{c}{ }^{\#} \text { Lower levels of } \\
\text { mycotoxin }\end{array}$ & $\begin{array}{l}{ }^{\#} \text { Higher levels of } \\
\text { mycotoxin }\end{array}$ & Means & $P$ \\
\hline & \multicolumn{4}{|c|}{ Weight (kg): Day 1} \\
\hline Without SDPP & $7.33 \pm 0.4$ & $7.30 \pm 0.6$ & $7.31 \pm 0.5$ & 0.91 \\
\hline With SDPP & $7.28 \pm 0.5$ & $7.35 \pm 0.6$ & $7.31 \pm 0.5$ & 0.90 \\
\hline Means & $7.30 \pm 0.4$ & $7.32 \pm 0.6$ & & 0.86 \\
\hline \multirow[t]{2}{*}{$P$} & 0.51 & 0.88 & 0.97 & \\
\hline & \multicolumn{4}{|c|}{ Weight (kg): Day 15} \\
\hline Without SDPP & $12.8 \pm 1.12$ & $11.2 \pm 0.86$ & $12.0 \pm 0.9$ & 0.05 \\
\hline With SDPP & $13.6 \pm 1.13$ & $13.7 \pm 1.22^{\mathrm{A}}$ & $13.6 \pm 1.1$ & 0.93 \\
\hline Means & $13.2 \pm 1.1$ & $12.4 \pm 1.0$ & & 0.17 \\
\hline \multirow[t]{2}{*}{$P$} & 0.38 & 0.03 & 0.12 & \\
\hline & \multicolumn{4}{|c|}{ Weight gain $(\mathrm{kg})$ : Day 1-15 } \\
\hline Without SDPP & $5.3 \pm 1.20$ & $3.9 \pm 0.91$ & $4.6 \pm 1.0$ & 0.01 \\
\hline With SDPP & $6.3 \pm 0.82$ & $6.3 \pm 0.86$ & $6.3 \pm 0.8$ & 0.98 \\
\hline Means & $5.8 \pm 1.0$ & $5.1 \pm 0.8$ & & 0.57 \\
\hline$P$ & 0.29 & 0.001 & 0.001 & \\
\hline
\end{tabular}

Note: Different to $P<0.05$ ( $n=14$ per group) by the F test. "Lower levels of mycotoxin (Groups CTL and SDPP $=0.95 \mu \mathrm{g} / \mathrm{kg}$ aflatoxins and $450 \mu \mathrm{g} / \mathrm{kg}$ fumonisins) and Higher levels of mycotoxin (Groups MYC and MYC $+\mathrm{SDPP}=300 \mu \mathrm{g} / \mathrm{kg}$ aflatoxins and $8,000 \mu \mathrm{g} / \mathrm{kg}$ fumonisins).

anti-inflammatory and reducing proinflammatory cytokines, since proinflammatory cytokines lead to oxidative stress.

Oxidative stress has a negative impact on the performance of pigs, and the detection of this imbalance and the factors that lead to this condition is important to reestablish balance and promote the health of the pigs (Bezerra et al. 2015). The mechanisms of the antioxidant effect of SDPP have not been elucidated. However, based on the results of the present study it can be suggested that SDPP provided a protective effect and avoided the condition of oxidative stress caused by the ingestion of diets containing aflatoxins and fumonisins.

\section{CONCLUSION}

Mycotoxins caused subclinical intoxication in the piglets and altered high-sensitivity cell lesion biomarkers, which characterize a situation of oxidative stress. In contrast, SDPP showed a cellular protective effect and avoided the exacerbation of oxidative reactions. Additionally, treatment stimulated the activity of the antioxidant enzyme SOD. The addition of SDPP to diets also provided better utilization of dietary protein by postweaning piglets with reduction of plasma urea. In addition, the use of SDPP as a supplement stimulated the performance of the animals, which had greater weight gain at the end of the study. Therefore, SDPP had beneficial effects for the production system and health of the litters, protecting against the negative effects of the mycotoxin present in the diet.

\section{REFERENCES}

ALI SF, LEBEL CP AND BONDY SC. 1992. Reactive oxygen species formation as a biomarker of methylmercury and trimethyltin neurotoxicity. Neurotoxicol 113(4): 637-648. 
BASS DA, PARCE JW, DECHATELET LR, SZEJDA P, SEEDS MC AND THOMAS M. 1983. Flow cytometric studies of oxidative product formation by neurotrophils: a graded response to membrane stimulation. J Immunol 130(4): 1910-1917.

BEZERRA BMO, EVANGELISTA JNB AND PINHEIRO DCSN. 2015. Impactos do estresse oxidativo na produção intensiva de suínos: desafios e perspectivas. Uma Revisão. Rev Bras Hig San An 9(5): 699-715.

CAMPBELL J, CRENSAHW J, RUSSELL L, HAYES S, BARANCELLI GV AND RANGEL LFS. 2008. Uso do plasma para modular a resposta inflamatória e o seu impacto na produção de suínos. Acta Sci Vet 36(1): 53-59.

CAMPBELL JM, POLO J AND CRENSHAW J. 2016. Orally fed spray dried plasma modulated the immune response during respiratory challenges: A review. J Anim Sci 94(1): 45-47.

CROMWELL GL. 2009. ASAS Centenial paper: Landmark discoveries in swine nutrition in the past century. J Anim Sci 87(6): 778-792.

DALTO DB ET AL. 2011. Plasma sanguíneo desidratado na recuperação de leitões leves ao desmame: desempenho zootécnico, perfil hematológico, frequência de diarreia e viabilidade econômica. Semina Ciênc Agr 32(Suppl. 1): 1989-2000.

DILKIN P, DIREITO G, SIMAS MMS, MALLMANN CA AND CORREA B. 2010. Toxicokinetics and toxicological effects of single oral dose of fumonisin B1 containing Fusarium verticillioides culture material in weaned piglets. Chem Biol Int 185(2): 157-162.

ERMER PM, MILLER P AND LEWIS AJ. 1994. Diet preference and meal patterns of weanling pigs offered diets containing either spray-dried porcine plasma or dried skim milk. J Anim Sci 72(6): 1548-1554.

FREITAS BV, MOTA MM, DEL SANTO TA, AFONSO ER, SILVA CC, UTIMI NBP, BARBOSA LCGS, VILELA FG AND ARAÚJO LF. 2012. Mycotoxicosis in Swine: a Review. J An Product Adv 2(4): 174-181.

FU JC, CHEN Q, SHI BM AND SHAN AS. 2013. Effectiveness of maifanite in reducing the detrimental effects of aflatoxin B1 on hematology, aflatoxin B1 residues, and antioxidant enzymes activities of weanling piglets. Livest Sci 157(2): 218-224.

GAO YY, JIANG ZY, LIN YC, ZHENG CT, ZHOU GL AND CHEN F. 2014. Effects of spray-dried animal plasma on serous and intestinal redox status and cytokines of neonatal piglets. J Anim Sci 89(1): 1-8.

HEDEGAARD CJ, STRUBE ML, HANSEN MB, LINDVED BK, LIHME A, BOYE M AND HEEGAARD PMH. 2016. Natural pig plasma immunoglobulins have antibacterial effects: potential for use as feed supplement for treatment of intestinal infections in pigs. PLoS ONE 11(1): e0147373.
JENTZSCH AM, BACHMANN H, FURST P AND BIESALSKI HK. 1996. Improved analisys of malondialdehyde in human body fluids. Free Rad Biol Med 20(3): 251-256.

MCCORD JM AND FRIDOVICH I. 1969. Superoxide dismutase. An enzymic function for erythrocuprein (hemocuprein). J Biol Chem 244(22): 6049-6055.

MULLER LKF, DA SILVA AS, BALDISSERA MD, SANTURIO JM, GLOMBOWSKY P, GUGEL J, CAMPIGOTTO G, GLORIA EM, PAIANO D AND MACHADO G. 2017. Effect of supplementation with spray-dried porcine plasma on blood variables on piglets feed with diet contaminated by mycotoxins. Microb Pathog 110(3): 464-470.

NELSON DL AND KIESOW LA. 1972. Entalpy of the composition of hydrogen peroxide by catalase at 25 ${ }^{\circ} \mathrm{C}$. Anal Biochem 49: 474-479.

OHKAWA H, OHISHI N AND YAGI K. 1978. Assay for lipid peroxides in animal tissues by thiobarbituric acid reaction. Anal Biochem 95(3): 351-358.

OLINDA RG, LIMA JM, LUCENA RB, VALE AM, BATISTA JS, BARROS CSL, CORREA FR AND DANTAS AFM. 2016. Aflatoxicose aguda em suínos no Nordeste do Brasil. Acta Sci Vet 44(Suppl. 1): 24.

OLIVEIRA AC, VALENTIM IB, GOULART MOF, SILVA CA, BECHARA EJH AND TREVISAN MTS. 2009. Fontes vegetais naturais de antioxidantes. Quim Nova 32(3): 689-702.

PASTORELLI H, MILGEN JV, LOVATTO P AND MONTAGNE L. 2012. Meta-analysis of feed intake and growth responses of growing pigs after a sanitary challenge. Animal 6(6): 952-961.

PEREZ-BOSQUE A, MIRÓ L, AMAT C, POLO J AND MORETÓ M. 2016. The anti-inflammatory effect of spray-dried plasma is mediated by a reduction in mucosal lymphocyte activation and infiltration in a mouse model of intestinal inflammation. Nutrients 8(10): E657.

PUJOLS J, SEGALÉS J, POLO J, RODRIGUEZ C, CAMPBELL J AND CRENSHAW J. 2016. Influence of spray dried porcine plasma in starter diets associated with a conventional vaccination program on wean to finish performance. Porcine Health Manag 2: 4.

ROSTAGNO HS, ALBINO LFT, DONZELE JL, GOMES PC, OLIVEIRA RF, LOPES DC, FERREIRA AS, BARRETO STL AND EUCLIDES RF. 2011. Exigências Nutricionais de Leitões de Alto Potencial Genético na Fase Pré-Inicial - Machos Castrados, Fêmeas e Machos Inteiros. Tabelas Brasileiras para Aves e Suínos: Composição de Alimentos e Exigências Nutricionais, $3^{\mathrm{a}}$ ed., Universidade Federal de Viçosa, Departamento de Zootecnia, Viçosa, p. 1-252.

SOARES ER, MONTEIRO EB, SILVA RC, BATISTA A, SOBREIRAF, MATOS T, COSTACA AND DALEPRANE JB. 2015. Compostos bioativos em alimentos, estresse 
oxidativo e inflamação: uma visão molecular da nutrição. Rev Hupe 14(1): 64-72.

SUGIHARTO S, HEEMANN MS AND LURIDSEN C. 2014. Plasma metabolomic profiles and immune responses of piglets after weaning and challenge with E. coli. J Anim Sci Biotechnol 5: 1-8.

TEIXEIRA AO, LOPES DC, FERREIRA AS, DONZELE JL, COSTA IRS, OLIVEIRA RFM, FERREIRA VPA AND SOUZAAVC. 2003. Efeito de Dietas Simples e Complexas sobre a Morfo-fisiologia gastrintestinal de leitões até 35 dias de idade. Rev Bras Zootec 32(7): 926-934.

THEUMER MG, CÁNEPA MC, LOPEZ AG, MARY VS, DAMBOLENA JS AND RUBINSTEIN HR. 2010. Subchronic mycotoxicoses in Wistar rats: Assessment of the in vivo and in vitro genotoxicity induced by fumonisins and aflatoxin B1, and oxidative stress biomarkers status. Toxicol 268(1): 104-110.

TORRALLARDONA D. 2010. Spray dried animal plasma as an alternative to antibiotics in weanling pigs - a review. Asian-Aust J Anim Sci 23(1): 131-148.

TRAN H, BUNDY JW, LI YS, CARNEY-HINKLE EE, MILLER PS AND BURKEY TE. 2014. Effects of spraydried porcine plasma on growth performance, immune response, total antioxidant capacity, and gut morphology of nursery pigs. J Anim Sci 92(10): 4494-4504.

WEAVER AC, CAMPBELL JM, CRENSHAW JD, POLO J AND KIM SW. 2014. Efficacy of dietary spray dried plasma protein to mitigate the negative effects on performance of pigs fed diets with corn naturally contaminated with multiple mycotoxins. J Anim Sci 92(9): 3878-3886. 